\title{
Geology and Shale Gas Potential of European Sedimentary Basinsan Overview
}

Hans-Martin Schulz \& Brian Horsfield (German Research Centre for Geosciences GFZ)

\section{Introduction}

Many parts of Europe contain prime targets for shale gas exploration. But compared to North America, Europe has a much more complex and compartimentalized setting of geological units. 510 Tcf shale-gas resources were estimated for Western Europe in 1997 by H.-H. Rogner, but the latest estimation by IHS CERA offers a much more optimistic number of 1000 Tcf ("Europe May Match North America in Unconventional Gas Promise").

Palaeozoic and Mesozoic black shales that are attractive for shale gas exploration occur in many European basins where conventional production is declining, an underutilized gathering infrastructure exists and markets are accessible.

With the exception of the biogenic shale gas in the Upper Devonian Antrim Shale (Michigan Basin), U.S. gas shales are exploited exclusively for thermogenic gas. In Europe several regional shale gas plays are assumed to contain thermogenic shale gas. The geologically oldest plays occur in Lower Palaeozoic sediments (the Cambro-Ordovician Alum Shale in Sweden and Denmark, and the Silurian graptolitic shale in Poland and Ukraine). Marine black shales of Dinantian age represent a stratigraphically younger major play option. A shale gas potential of isochronous horizons in the Northwest European Carboniferous Basin is represented by the Bowland shale (UK), the Epen Formation (The Netherlands), the Kulm (Poland), and Tournaisian and Namurian black shales in Germany. Additionally, Visean black shales in the Dniepr-Donets rift basin can contain shale gas. The Mesozoic shale gas play comprises Lower or Upper Jurassic black shales in the Weald Basin (UK), in the Lower Saxony Basin (Germany) and in the Vienna basin (Austria), but Wealden deposits in the Lower Saxony Basin are also of interest for exploration. In contrast to thermogenic shale gas targets an additional shale gas potential exists for biogenic methane. Biogenic shale gas occurs in Oligocene to Miocene sediments of the Molasse belt north of the Carpathian-Alpine mountain belt, and also -by analogy to the Antrim Shale- in northern areas which were covered by Pleistocene glaciers.

Potential European shale gas systems are variable in composition and extent, as are the successful shale gas systems in North America. In this presentation, European black shales of different geological age will be introduced, which can be siliciclastic-dominated shales and/or carbonateinfluenced mudstones. Both lithological systems are result of different depositional histories and exhibit different lateral and vertical sediment architectures. A focus will be on the individual histories of organic carbon production and preservation, and the ensuing diagenetic pathways which determine shale gas potential and brittleness. Moreover, heat flow and tectonic histories which controlled thermal maturation, gas generation and adsorption, and thus shale gas resource will be presented. 